\title{
The Use of Warning Booklet to Improve the Knowledge and Attitude of Pregnant Women in Early Detection of Pregnancy Complications in Karawang Regency
}

\author{
Warliana Ombi,(D), Eneng Sholihah (D), Gurid Pramintarto Eko Mulyo*(i) \\ Poltekkes Kemenkes Bandung, Indonesia
}

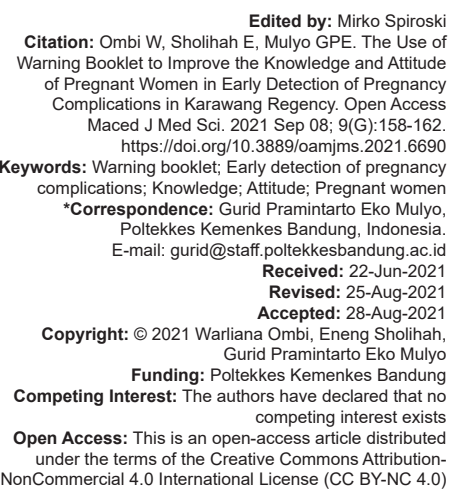

Edited by: Mirko Spirosk Citation: Ombi W, Sholihah E, Mulyo GPE. The Use of Warning Booklet to Improve the Knowledge and Attitude of Pregnant Women in Early Detection of Pregnancy Complications in Karawang Regency. Open Access Maced J Med Sci. 2021 Sep 08; 9(G):158-162. https://doi.org/10.3889/oamjms.2021.6690 Keywords: Warning booklet; Early detection of pregnancy complications; Knowledge; Attitude; Pregnant women
*Correspondence: Gurid Pramintarto Eko Mulyo, Pondekkes Kemenkes Bandung Eko Mulyo,
Polndonesia Poltekkes Kemenkes Bandung, Indonesia. Received: 22-Jun-2021 Revised: 25-Aug-202 Accepted: 28-Aug-2021 competing interest exists Open Access: This is an open-access article distribute under the terms of the Creative Commons Attribution-
NonCommercial 4.0 International License (CC BY-NC 4.0)

\begin{abstract}
BACKGROUND: The strategy for reducing maternal mortality is through increasing empowerment of women, families, and communities. Families are expected to play an active role in knowing and making efforts to prevent maternal and infant morbidity and mortality - the number of cases of maternal death in Kab. Karawang in 2015 and 2016, respectively, as many as 68 cases and 61 cases, the main causes are preeclampsia, bleeding, and comorbidities.

AIM: The aim is to determine the effect of warning's booklet on increasing knowledge and attitudes of pregnant women toward early detection of pregnancy complications.

METHODS: The research design used a quasi-experimental design, non-equivalent control group. The research location was carried out in the areas of Purwasari Health Center and Rengasdengklok Health Center. The population is pregnant women in trimester I-III, with a total sample of 70 respondents. The analysis test used t-test and MannWhitney U-test. The sampling technique used purposive random sampling

RESULTS: Degree of significance 0.05 ; with a $5 \%$ confidence level.

CONCLUSION: Warning's booklet means increasing knowledge of early detection of pregnancy complications and
\end{abstract} increasing attitudes toward early detection of pregnancy complications pre-test 37.89 and posttest 46.40 .

\section{Introduction}

One of the strategies used to reduce maternal mortality is increasing the empowerment of women, families, and communities [1]. Through the family's active role, the family is expected to know and be able to make efforts that must be made to prevent pain and death for the mother and her baby so that they can give birth safely and prosperously during the interval.

Indonesia is one of the five contributing countries to the maternal mortality rate in ASEAN and ranks $4^{\text {th }}$ before Laos and well below neighboring Malaysia and Singapore. The number of maternal deaths based on an intercensus survey report in 2017 was $305 / 100,000 \mathrm{KH}$. Maternal mortality is inseparable from the incidence of obstetric complications that occur in pregnant women as well as other factors that affect them. The highest maternal mortality in Indonesia was $40.80 \%$, bleeding $30.3 \%$, hypertension $27.1 \%$, and infection $7.3 \%$ [2].

Promotional media is any means or efforts to display the message of information that the communicator wants to convey so that the target can increase his knowledge which is finally expected to change his behavior positively toward health. Some understandings of media counseling have several understandings, as follows: (a) All the means and tools used in the process of delivering messages. (b) Media counseling is a vehicle to channel messages from the sender to the recipient to stimulate thoughts, feelings, and attention/interests. (c) All means or efforts to display the message of information that the communicator wants to convey so that the target can increase his knowledge which is finally expected to change his behavior positively toward health [2].

Based on the role, the media plays a significant role in the implementation of health counseling, including: Can facilitate the delivery of information, avoid misperceptions, clarify information, facilitate understanding, reduce verbalizes communication, display objects that cannot be captured with the eyes, and facilitate communication.

Types of health promotional media are various such as print media, electronic media, and outdoor media, and other media. The print media is a medium whose delivery method prioritizes the visual messages, usually consisting of a picture of several words, images, 
or photos in the color layout. Included in this medium are booklets, leaflets, flyers, flip charts, rubrics, or writings in newspapers or magazines, posters, and photos that reveal health information. There are several advantages of print media such as durable, include many people, low cost, can be to carry everywhere, do not need electricity, facilitate understanding, and can increase the passion for learning. Print media has the disadvantage of not stimulating motion effects and sound effects and easily folded [2].

Media booklets are one part of the types of print media containing messages in visual form. A booklet is a medium to convey health messages in the form of books containing writings and pictures. A booklet is a booklet of no more than 24 pieces [3].

Booklets are small (half quarto) and thin, with no more than 30 pieces of back and forth containing writings and pictures. The term booklet comes from books, and leaflets mean media booklet is a combination of leaflets and books with a small format (size) such as leaflets. The structure of the booklet's contents resembles a book (introduction, content, and closing); it's just that the way the content is presented is much shorter than the book. Booklets are prints with a unique book-shaped look. The creation of the contents of the booklet is no different from the creation of other media. The thing to note in making a booklet is how we compose the material as attractive as possible. When one glances into the booklet, usually, the first concern is on the side of the view first.

A booklet is a print media in the form of a book that provides information on what the author wants to convey. The reasons for choosing a booklet as a medium of information about the lifestyle of hedonism are as follows: (1) Booklet can help counselors in helping students get complete information about the lifestyle of hedonism, (2) booklet is a learning material that is specifically designed systematically, interestingly, and accompanied by illustrations of images so that students can quickly learn independently, (3) booklet can help counselors provide an understanding of the lifestyle of hedonism in students. Permatasari (2004) explained that the booklet is a medium of communication that is promotional, advisable, prohibitions to the masses, and in the form of prints, which has the purpose that the public as objects can understand the message conveyed through this media. Print media such as booklets has the advantage that they can be learned at any time because the design is in the form of a book, can be learned independently by students, messages, or information relatively more than posters, attractive booklet design makes students will be interested in reading it [4].

Booklet development needs to provide references (reading materials) for community groups with limited access to sourcebooks because of their limitations. With this community, the booklet can gain knowledge such as reading books, short reading time, and under any circumstances. The advantages are; can be used as a medium or tool for self-learning, can be learned its contents quickly, can be used as information for family and friends, easy to create, reproduced, improved and adjusted, reduce the need to take notes and can be made and cost relatively cheap and durable and has a broader capacity, and can be directed to a specific segment.

Booklets as print media have limitations, according to Anderson, 1994:169, quoted in Gustaning, namely: It takes a long time to print depending on the message to be delivered, and the tools used to print, difficulty displaying motion on the page, messages, or information that is too much and long will reduce the intention to read the media, need good care so that the media is not damaged and lost. From the above statement can be concluded as a print media, booklets have the advantage of being made quickly and cost relatively cheap and more durable compared to audio and visual media as well as audiovisual. Booklets are usually used for knowledge improvement purposes, as they provide more specific information. Booklet limitations as a print media take a long time to print depending on the message and tools, relatively expensive to print images or photos, difficulty displaying motion on the page, can reduce the reader's interest if too much and long, and the need for intensive care [5].

\section{Method}

The design uses quasi-experimental design in the form of non-equivalent control group design, two groups pretest-posttest, namely, control and intervention group. In this design, two groups were given interventions, both control groups, and interventions. Only the samples were not selected randomly.

The research was conducted from March 2019 until November 2019, with research locations in two places, namely, Purwasari Health Center and Rengasdengklok Health Center. Different locations in the two puskesmas areas are due to several puskesmas adjacent to Purwasari Health Center in preparation for accreditation so that difficulties in moving respondents. The research area in Purwasari and Rengasdengklok subdistricts was chosen based on several years behind the occurrence of referral cases of pregnant women at risk, especially preeclampsia quite a lot, the other basis is based on information data reports KIA distribution of $\mathrm{KIA}$ books is less even. There are still many pregnant women who do not get KIA books, and there are some pregnant women who have not followed the mother class.

The population in this study was pregnant women living in the research area. The samples are pregnant women trimester I, II, and III who have met 
inclusion and exclusion criteria. Pregnant women with a history of chronic diseases such as heart disease, tuberculosis, and diabetes are excluded from the study. The number of samples in the intervention and control group in each 35 purposive sampling respondents was the sampling method taken in this study. The instrument in this study is booklet warning which contains information on pregnancy hazard signs and temporary action information before referral or to health workers that the mother should do in case of midwifery.

\section{Results}

\section{Characteristics of respondents}

Based on Table 1, the distribution of respondents' frequency based on characteristics obtained a picture of maternal age in the control group, and interventions were mainly in healthy reproduction. At the same time, there were 10 respondents (88.6\%) at a high-risk age, maternal education in the intervention group of 31 respondents (88.6\%) in low education, the participation of maternal class activities in both the control group and interventions has mostly followed the mother's class as the following results are as follows: 27 respondents $(77.1 \%)$ control group and 28 respondents $(80 \%)$ intervention group.

\begin{tabular}{|c|c|c|}
\hline \multirow[t]{2}{*}{ Characteristics } & \multicolumn{2}{|l|}{ Group } \\
\hline & Control & Intervention \\
\hline \multicolumn{3}{|l|}{ Mother's age } \\
\hline Healthy reproduction & $31(88.6 \%)$ & $25(71.4 \%)$ \\
\hline High risk & $4(11.4 \%)$ & $10(28.6 \%)$ \\
\hline \multicolumn{3}{|l|}{ Mother's education } \\
\hline High & $18(51.4 \%)$ & $4(11.4 \%)$ \\
\hline Low & $17(48.6 \%)$ & $31(88.6 \%)$ \\
\hline \multicolumn{3}{|l|}{ Mother class } \\
\hline Yes & $27(77.1 \%)$ & $28(80 \%)$ \\
\hline No & $8(22.9 \%)$ & $7(20 \%)$ \\
\hline \multicolumn{3}{|l|}{ Pregnancy status } \\
\hline Prigravida & $9(25.7 \%)$ & $8(22.9 \%)$ \\
\hline Multigravida & $26(74.3 \%)$ & $27(77.1 \%)$ \\
\hline
\end{tabular}

Based on Table 2, the results of the interim study showed the average score of knowledge of respondents in the pre-test of 2.8 . In contrast, the posttest of $16,015.57$, the figure showed an increase in the knowledge score in the group of pregnant women who were given a booklet, and the average attitude score showed a pre-test score of 37.89 and post-test 46.40 , based on the figure showed an increase in the attitude of pregnant women after being given intervention through booklet.

Table 2: Results of knowledge and attitudes of experimental intervention groups before and after intervention $(n=2135)$

\begin{tabular}{llllll}
\hline Variable & $\mathrm{n}$ & Median (min-max) & Mean & SD & $\mathrm{Cl} 95 \%$ \\
\hline Knowledge & & & & & $4.50-7.79$ \\
$\quad$ Pre-test & 35 & $6(2-17)$ & 2.8 & 1.07 & \\
$\quad$ Post-test & 35 & $16(14-18)$ & 16.01 & 1.19 & \\
Attitude & & & & & \\
$\quad$ Pre-test & 35 & $37(27-49)$ & 37.89 & 4.83 & $45.31-47.49$ \\
$\quad$ Post-test & 35 & $45(36-50)$ & 46.40 & 3.18 & \\
\hline Cl: Confidence level & & & & &
\end{tabular}

Based on Table 3, test results differed average pretest-posttest knowledge respondents in the intervention group with a booklet obtained t-test results of $-11,923$ and $p=0.000$ so that Ho conclusion knowledge is rejected, which means that there is a difference in knowledge about early detection of pregnancy complications between before and after health education with the media warning booklet.

Table 3: Analysis of paired t-test knowledge and attitudes in intervention groups

\begin{tabular}{lllll}
\hline Variable & Mean & t- test & $p$ value & $\mathrm{Cl} 95 \%$ \\
\hline Knowledge & & & & \\
$\quad$ Pre-test & 6.14 & -11.923 & 0.000 & $(-11.069)-(-7.845)$ \\
$\quad$ Post-test & 15.60 & & & \\
Attitude & & & & \\
$\quad$ Pre-test & 37.89 & -11.567 & 0.000 & $(-10.010)-(-7.018)$ \\
$\quad$ Post-test & 46.40 & & & \\
\hline Cl: Confidence level & & & &
\end{tabular}

Similarly, the results of the test average pretest-posttest on the attitude of respondents to the management of pregnancy complications by showing the results of the t-test of $-11,567$ and $p=0.000$ so that the conclusion $\mathrm{Ho}$ attitude rejected which means that there is a difference in attitude to the management of pregnancy complications between before and after the health education with the media booklet warning.

\section{Discussion}

\section{Differences in knowledge about early detection of pregnancy complications before and after being given the booklet warning early detection of pregnancy complications}

Based on the results of the study showed the average score of knowledge of respondents in the pretest of 2.8 while the post-test amounted to 16.01 , the figure showed an increase in the value of knowledge in the group of pregnant women who were given a booklet warning detection of pregnancy complications and the results of different tests average pretestposttest knowledge of respondents in the intervention group with booklets obtained t-test results of $-11,923$ and $p=0.000$ so that it can be concluded that there is the influence of knowledge about early detection of pregnancy complications between before and after health education using warning media booklets.

Based on the role, the media is a very important role in the implementation of health counseling, including: Can facilitate the delivery of information, avoid misperceptions, clarify information, facilitate understanding, reduce verbalizes communication, display objects that cannot be captured with the eyes, and facilitate communication [2].

Booklet development is the need to provide references (reading materials) for community groups who have limited access to sourcebooks because of 
their limitations. With this community, the booklet can gain knowledge such as reading books, with a short reading time, and under any circumstances. The advantages are; can be used as a medium or tool for self-learning, can be learned its contents easily, can be used as information for family and friends, easy to create, reproduced, improved and adjusted, reduce the need to take notes and can be made and cost relatively cheap and durable and has a broader capacity, and can be directed to a certain segment [5].

Although the test results differed in average pretest-posttest knowledge of respondents in the control group, using counseling techniques obtained t-test results of -9362 and $p=0.000$ that indicates knowledge about early detection of pregnancy complications between before and after health education by utilizing counseling detection of pregnancy complications which shows meaningful value. Hence, on the increase of knowledge, there is no difference between control and intervention groups.

The results of this study, following the results of Sari's research (2018) bouquet, influence improving the impact of adolescent pregnancy, and the results of Pratiwi's research (2017) showed a significant influence on knowledge in respondents given booklets [6]. The similarity of the materials provided has an impact on the change of knowledge in the control group. This can also be influenced by the characteristic background of respondents in the control group, which is more balanced in the level of education, mostly with a middle education background while the intervention group is more likely to have low education. Thus, it allowed the control group to receive information more easily than the intervention group so that the results of increased knowledge had a positive impact for both groups.

\section{Differences in attitudes on early detection of pregnancy complications before and after being given the booklet warning early detection of pregnancy complications}

Based on the results of the average attitude score in the intervention group, booklet showed a pretest attitude score of 37.89 and post-test 46.40 , based on the figures showed an increase in the attitude of pregnant women after being given intervention through booklets warning detection of pregnancy complications. Similarly, the results of the average pretest-posttest test on respondents' attitude to the management of pregnancy complications showed the t-test of $-11,567$ and $p=0.000$, so that the conclusion means that the booklet warning early detection of pregnancy complications has an influence on the change in attitude to the management of pregnancy complications.

While in the control group, the average score of attitude to the incidence of pregnancy complications and early treatment at home showed a pre-test score of 38.29 and post-test 39.40 , based on the figures shown, the increase in the attitude of pregnant women in the control group did not have much impact. While the results of the t-test average pretest-posttest on respondents' attitude to the management of pregnancy complications, by showing the results of t-test of -0.745 and $p=0.462$, means that pregnant women who do not get intervention using warning booklets in detecting pregnancy complications do not show a change in the attitude to the management of pregnancy complications at the family level. The results of the study, in line with Puspitaningrum research (2017), showed that health education with media booklets has a significant influence on improving young women's attitudes with $p=0.0001$. Attitude, according to Marisa, is influenced by various factors, one of which is education or education. Media is also one of the factors that influence one's attitude. Useful media generates target interest, stimulates goals to forward messages to others, and facilitates information delivery. Media serves to facilitate a person in understanding information that is considered complicated [7]. Human attitude is a willingness to respond or act on something. Attitude is also defined as a state of preparedness that is learned to respond consistently to certain objects that lead to favorable and unfavorable directions. Azwar, in Ananda (2009), classifies the definition of attitude into three frames of mind. First, attitude is a form of reaction or evaluation of feelings. In this case, one's attitude toward a particular object is impartial or impartial. Second, attitude is the readiness to react to certain objects; third, attitude constellates cognitive, affective, and conative components that interact with each other.

The results showed that the media booklet warning detection of pregnancy complications makes it easier for pregnant women to understand information about pregnancy complications in determining the attitude to be done when complications occur.

\section{Conclusion}

There is a difference in the knowledge of pregnant women about early detection of pregnancy complications between before and after being given health education using the media booklet warning early detection of pregnancy complications $(p=0.000)$.

There is a difference in the attitude of pregnant women to early detection of pregnancy complications between before and after being given booklet warning early detection of pregnancy complications $(p=0.000)$.

\section{Suggestion}

For pregnant women and families to continuously improve the knowledge and attitude as 
to detect pregnancy complications and perform simple pre-referral treatment at the household level.

\section{References}

1. Depkes RI. Buku Pedoman P4K. Indonesia: Depkes RI; 2009.

2. Kementerian Kesehatan Republik Indonesia. Profil Kesehatan Indonesia 2016. Profil Kesehatan Provinsi Bali; 2016. p. 1-220. https://doi.org/10.7454/epidkes.v1i1.1314

3. Agustin M. Efektifitas pendidikan kesehatan media booklet dibandingkan audiovisual terhadap pengetahuan orang tua tentang karies gigi pada anak usia 5-9 tahun di desa Makamhaji. J Chem Inf Model. 2013;53(9):1689-99. https://doi. org/10.32382/mkg.v20i1.2166

4. Gemilang R, Christiana E. Pengembangan booklet sebagai media layanan informasi untuk pemahaman gaya hidup hedonisme siswa kelas xi di sman 3 Sidoarjo. Pendidikan. 2015;6:3-9.

5. Gustaning G. Pengembangan Media Booklet Menggambar Macam-Macam Celana Pada Kompetensi Dasar Menggambar Celana Siswa Smkn 1 Jenar. Indonesia: Universitas Muhammadiyah Surakarta; 2014.

6. Pratiwi YF, Puspitasari DI. Efektivitas penggunaan media booklet terhadap pengetahuan gizi seimbang pada ibu balita gizi kurang di kelurahan semanggi kecamatan pasar kliwon Kota Surakarta. J Kesehat. 2017;10(1):58. https://doi.org/10.23917/ jurkes.v10i1.5493

7. Puspitaningrum W, Agushybana F, Mawarni A, Nugroho D. Wanodya puspitaningrum, farid agushybana, atik mawarni, Djoko Nugroho. J Kes Masy. 2017;5:274-81. 